\title{
Admissibility Clause-dilemma Facing the ICC and the Concern of War in the Gaza Strip
}

\author{
Peter Onyango Onyoyo
}

School of Law, University of Nairobi, Kenya

Copyright (C) 2015 Horizon Research Publishing All rights reserved.

\begin{abstract}
This researched paper is an exposure of key legal challenges facing the international criminal justice framework and its effectiveness in the $21^{\text {st }}$ Century. The Arab-Israeli war, Israel Palestinian War, Israel-Hamas War, Israel versus Islam nations in the Middle East, have been historical events whose legal solution appear always to be dwindling with time. It is in the interest of the author to open up some of the critical problematic questions under discussion by international lawyers and diplomats about the atrocities going on in the Middle East region and especially in Palestine and Israel. However, the article does not give an illusion of an immediate legal solution to the problem that has been affecting many civilians, civilian populations with their objects being destroyed with impunity. It is noted that the hostilities taking place in the Gaza Strip and the entire region present a very delicate situation in the development of international criminal justice system. It is in the interest of the article to provide points for intellectual considerations before making conclusions. You can download the entire research.
\end{abstract}

Keywords Judicial Discretion of the ICC, World Politics and International Law, Humanitarian Cost, Use of Force, Locus Standi, and Admissibility

\section{Background}

The genesis of armed Conflicts between Israel and Palestine can be traced back many decades before the establishment of the International Criminal Court (ICC) in 2002. The chronic war and crimes of aggression taking place in the region ${ }^{1}$ have been the epitome of serious debates, discussions, diplomatic turmoil and cruelty involving both Israel and Palestine. ${ }^{2}$ Meanwhile both sovereignties have been equally engaged trading in blame game and lip

\footnotetext{
'Palestinians Accuse Israel of War Crimes, Push for ICC Trial Gets Support Online'

$<$ http://globalvoicesonline.org/2014/07/26/palestinians-accuse-israel-of-wa r-crime-push-for-icc-trial-gets-support-online/> accessed 4 August 2014.

Ibid.
}

services ${ }^{3}$ while violating international humanitarian and human rights law ${ }^{4}$ with impunity. ${ }^{5}$ Reprisals, missile attacks, suicide bombing, illegitimate occupation of Palestinian territory by Israel authorities, target killing of some members of Hamas, and Al Fatah have been some of the alleged war crimes shocking the conscience of humanity. ${ }^{6}$ As already clearly stated in the preamble of the Rome Statute such grave crimes threaten peace, security and the well-being of the world. ${ }^{7}$ The Court was established to deal with war crimes, crimes of aggression, genocide crimes and, inter alia, the impunity. ${ }^{8}$ Israel and Palestine have severally resorted to the use of force ${ }^{9}$ as means of solving their differences despite the UN Charter and the draft resolution A/C6/39/L9 of the United Nations General Assembly condemning its use to settle disputes. ${ }^{10}$

It is in the best interest of this research to investigate the admissibility clause of the Rome Statute (Text of the Rome Statute circulated as document A/CONF.183/9 of 17 July 1998 and corrected by procès-verbaux of 10 November 1998 , 12 July 1999, 30 November 1999, 8 May 2000, 17 January 2001 and 16 January 2002. The Statute entered into force on 1 July 2002) ${ }^{11}$ which allows the Court to intervene and to expeditiously investigate the alleged crimes taking place in States. Can the ICC legally bring the perpetrators of the violence involving civilians and armed forces in Gaza Strip to international criminal adjudication process? ${ }^{12}$ Is the international criminal justice applicable and does the court really have jurisdiction over the on-going conflicts in the Strip of Gaza? Do the States concerned recognise the jurisdiction of the ICC?

Arguably, one may safely say that having the Rome

\footnotetext{
${ }^{3}$ Ibid.

${ }^{4}$ Graham, Malbone $\mathrm{W}$, Humanitarian Intervention in International Law as Related to the Practice of the United States (1920).

${ }_{5}^{5}$ Yves Beigbeder, International Justice Against Impunity Progress And New Challenges (Brill Academic Pub 2005).

${ }^{6}$ Yves Beigbeder, International Justice Against Impunity Progress And New Challenges (Brill Academic Pub 2005)

7 'ROME STATUTE.pdf'.

${ }^{8}$ Beigbeder (n 5).

'Use of Force and War' (1984) 11 Australian Year Book of International Law 577.

${ }^{10}$ Ibid.

11 'ROME STATUTE.pdf' (n 7).

12 'MILITARY LAW'.
} 
Statute ${ }^{13}$ and the United Nations Charter law, Human Rights law, Military Law of The Hague and International Humanitarian Law ${ }^{14}$, Arab League, as regulatory international authorities, serious heinous crimes should not occur anywhere in the world. Easier said than done the international criminal judicial bodies find it technically difficult to intervene in the Palestine-Israel conflicts. The reluctance of the United Nations Security Council is questionable. The failure of the world judicial authorities to quell the humanitarian disaster and restore law and order in the region is likewise questionable?

Rome Statute clearly states that the Office of the Chief Prosecutor (OTP) can apply the proprio motu provision under Art. 15(1) ${ }^{15}$ and open credible criminal investigation on a State as has been the case in Kenya. ICC Chief Prosecutor opens preliminary investigations in $\mathrm{Gaza}^{16}$ as the State of Palestine is applying to accede to the Rome Statute. The international community keeps on guessing the next cause of action while atrocities are still taking place both from Israeli and Gaza Strip fronts ${ }^{17}$. If the atrocities and crimes taking place in the Gaza Strip meet the threshold of the international crimes then the permanent International Criminal Court may lawfully proceed to full investigation into the crimes committed in Gaza ${ }^{18}$.

It is in order to question the admissibility of crimes caused by adverse hostilities and use of aggression in the Gaza Strip and Israel pursuant to the existing international law. ${ }^{19}$ Rome Statute that established the ICC makes it loud and clear that any State Party can bring its complaint about its national/s to the Court for any possible judicial consideration and the Court prosecutes persons deemed to bear the highest responsibility in the alleged crimes ${ }^{20}$ within its jurisdiction and not the sovereign States. ${ }^{21}$

Another condition is on the jurisdiction of the Court over the territory where the crime has occurred. ${ }^{22}$ This challenge shall only be addressed by statehood of Palestine and whether it is unable or unwilling to prosecute.

It is questionable whether the alleged heinous crimes committed in Gaza are within the jurisdiction of the ICC or not? ${ }^{23}$ In case this does not work, and the States concerned do not have judicial capacity or are reluctant (not willing) to

\footnotetext{
13 'ROME STATUTE.pdf' (n 7).

${ }_{14}$ Donja de Ruiter, Humanitarian Law Selected Documents (International Courts Association 2011).

15 'ROME STATUTE.pdf' (n 7).

16 'ICC Opens Investigation of Gaza War' $<$ http://honestreporting.com/idns-01182015-icc-investigation/ $>$ accessed 9 March 2015.

17 'ElementsOfCrimesEng.pdf'

$<$ http://www.icc-cpi.int/NR/rdonlyres/336923D8-A6AD-40EC-AD7B-45B F9DE73D56/0/ElementsOfCrimesEng.pdf> accessed 9 March 2015.

${ }_{18}$ 'ICC Opens Investigation of Gaza War' (n 16).

19 'Israel \& Palestine: A Tragedy in Three Acts' $<$ http://rt.com/op-edge/177764-israel-palestine-tragedy-argentina/> accessed 4 August 2014.

20 'ElementsOfCrimesEng.pdf' (n 17).

21 'UICCEng.pdf'

$<$ http://www.icc-cpi.int/iccdocs/PIDS/publications/UICCEng.pdf> accessed 6 August 2014

22 Jason Burke, 'Rafah Residents Count Human Cost of Israeli Offensive' The Guardian (3 August 2014) < http://www.theguardian.com/world/2014/ aug/03/rafah-residents-count-human-cost-israeli-offensive $>$ accessed 4 August 2014

23 Ibid.
}

investigate, and prosecute the perpetrator/s, the other cause for action shall be within the powers of the Office of the Prosecutor.

\section{Jurisdiction of the Court over War Crimes}

Under Art. 8 of the Rome Statute, the Court shall have jurisdiction in respect of war crimes in particular when committed as part of a plan or policy or as part of a large scale commission of such crimes. The same Article paragraph (b) in furtherance states that other serious violations of the laws and customs applicable in the international armed conflicts, within the established framework of international law, namely, any of the following acts: (i) intentionally directing attacks against the civilian population as such or against individual civilians not taking direct part in hostilities; (ii) intentionally directing attacks against civilian objects, that is, objects which are not military objectives; (iv) intentionally launching an attack in the knowledge that such attack will cause incidental loss of life or injury to civilians or damage to civilian objects or wide spread, long-term, or severe damage to the natural environment which would be clearly excessive in relation to the concrete and direct overall military advantage anticipated. $^{24}$

Even if in unequal proportions the above mentioned war crimes appear to have been committed both by Israel and Hamas Militant group in the Gaza Strip alike. And in case of any legal prosecution then both sides must be considered equally as grave breaches of the international criminal law in question.

Other provisions that require the attention of this research are pegged on the membership of the States in the ICC. ${ }^{25}$ Are Israel and Palestine signatories to the Rome Statute and if not what are the likely legal cause for action at the international criminal law perspective?

Prof. Eugene Kontorovich makes it clear in his discussion on unchartered State of Palestine the question of borders which still remains unclear within the international law even after the recognition of Palestine as a sovereign State. ${ }^{26}$ Once the national borders are defined and determined then it is agreeable to find out whether the scene of crime has taken place in Palestinian territory or occupied territory before proceeding to seek international criminal redress.

The Court may exercise its jurisdiction in situations where the alleged perpetrator is a national of a State Party or where the crime was committed in the territory of a State Party. Also, a State not party to the Statute may decide to accept the jurisdiction of the ICC. These conditions do not apply when the Security Council, acting under Chapter VII of the United Nations Charter, refers a situation to the Office

\footnotetext{
24 'ROME STATUTE.pdf' (n 7).

${ }^{25}$ John Dugard, 'Palestine and the International Criminal Court Institutional Failure or Bias?' (2013) 11 Journal of International Criminal Justice 563. 26 'Journal of International Criminal Justice' <http://jicj.oxfordjournals.org> accessed 7 August 2014.
} 
of the Prosecutor. ${ }^{27}$

The ICC does not have jurisdiction over States which are not signatories to the Rome Statute ${ }^{28}$ unless otherwise the situation is brought to the attention of the Court by the UN Security Council for consideration as in the case of Sudan. ${ }^{29}$

Most importantly the nature of the conflict may also contribute to the failure of the Court to claim jurisdiction over Palestine. The fight in the Gaza Strip has connection with many decades of historical criminal offences in the region. The Court does not have retroactive provision that allows it to deal with offences committed before its establishment therefore the ICC cannot prosecute criminal offences that happened before its inception in $2002 .{ }^{30}$

\section{Recognition of the State of Palestine}

It was on $27^{\text {th }}$ of September 2013 that $69.4 \%$ of the 193 States members of the United Nations recognised the State of Palestine after many years existing in international limbo. ${ }^{31}$ Yet still the Government, President Mahmoud Abbas of Al Fatah party, and that of Hamas ruling the West Bank and Gaza Strip, are not operating as a unitary Government for the State of Palestine representing the Palestinian people. They operate as two separate governments but in one State.

Hamas started as a militant movement that used force and military attacks against Israel (the occupier) as approach for liberation, while Al Fatah prefers diplomatic negotiations with Israel and the UN as the means to achieve full independence without resorting to violence.

Yet it is the Palestinian Liberation Organization (PLO) which has been recognised by the United Nations in 1974 as authority representing the rights of the Palestinian people and forging the process to the full recognition of the State of Palestine which should enjoy its de jure and de facto statehood within the international law. ${ }^{32}$ The PLO Executive Committee is empowered by the Palestinian National Council (l'Étát Majeur) to perform the functions of the Government of the State of Palestine but not Hamas which is a militant movement created to put military pressure on Israel.

The State of Israel was created in 1948, barely 3 years following the United Nations Charter which ended the World War II with full recognition of the USA and pro-zionist Christian States. Merged with historical facts, fights and several challenges in the region covering the present Palestine, Strip of Gaza, West Bank and Israel, the statehood of the State of Palestine has been problematic and difficult to ascertain through legal means. ${ }^{33}$

\footnotetext{
27 'UICCEng.pdf' (n 21).

${ }^{28}$ Eugene Kontorovich, 'Israel/Palestine — The ICC's Uncharted Territory' (2013) 11 Journal of International Criminal Justice 979

29 Dugard (n 25).

30 'UICCEng.pdf' (n 21)

31 'State of Palestine', , Wikipedia, the free encyclopedia (2014) $<$ http://en.wikipedia.org/w/index.php?title=State of Palestine\&oldid=619 424093> accessed 4 August 2014.

32 Ibid.

33 Caitlin Carenen, 'The American Christian Palestine Committee, the Holocaust, and Mainstream Protestant Zionism, 1938-1948' (2010) 24
}

Paradoxically Israel is a fully recognized State ${ }^{34}$ with member status by the United Nations (S/RES/69 of $4^{\text {th }}$ March 1949 and A/RES/273(III)). In exercising its State powers and jurisdiction, Israel has been occupying strategic historical sites in the Palestinian territory after the UN partition plan adopted by the General Assembly in 1948 and the Camp David Accord of 1967 that gave Jewish State some part of Jerusalem, while Jerusalem-Bethlehem under international protection.

Historical sites that define Judaism and Jewish faith must also be taken into serious consideration by the decision to give Palestine State Membership status. It is not going to be an easy task for Israel and pro-Zionism Christian supporters to allow Palestine to take over Jerusalem-Bethlehem as its capital, a move that may prejudice Judeo-Christian religious rights in the volatile region. Religious fact is in the interest of Christians who believe and traditionally follow the Biblical ${ }^{35}$ and Messianic writings for their faith. ${ }^{36}$

Hypothetically, the Palestinians who are mainly of Islamic faith and do not recognise Jesus as the Messiah or as God may not be tolerant enough to protect Judeo-Christian interests in the region. ${ }^{37}$ Purportedly, due to this historical fact Israel has had strong backing from the United States of America ${ }^{38}$ and many other Christian States that fear for possible damages of their religious stronghold. A similar doom has been witnessed in Mosul (in Iraq) where anti-Christian activists under the name Islamic State has destroyed the historical tomb of Jonah forcefully sending away Christians who were living there.

The militant group ISIS is continuing its rampage of holy places by destroying the tomb of Jonah, a place thought to be the burial site of the prophet believed by Abrahamic faiths to have been swallowed by a whale or fish. ${ }^{39}$ Convert or die order has been issued.

Such militant actions against groups of religious faith amount to Islamophobia and reluctance of certain States to support the cause of Palestinian-Israeli conflict. America is considering intervention in Iraq to stop the ravages, genocide, and mass executions based on religion. ${ }^{40}$

Historical wounds created by the Second World War on the Holocausts which adversely affected the Jews communities around the world, still inform the world public opinion concerning the decision on Israeli-Palestinian crisis. It is also on the historical European Anti-Semitism sentiment that the world superpowers have been protecting the integrity of Israel. Hatred against the Jewish people has been condemned and prohibited by the international law. Threats

\footnotetext{
Holocaust and Genocide Studies 273.

34 Ibid.

35 Ibid.

36 Ibid.

37 Ibid.

38 Ibid.

39 Yasmine Hafiz, 'ISIS Destroys Jonah's Tomb In Mosul, Iraq, As Militant

Violence Continues' (Huffington Post, 25 July 2014)

$<$ http://www.huffingtonpost.com/2014/07/25/isis-jonah-tomb n 5620520. html $>$ accessed 7 August 2014.

${ }_{40}$ 'Airstrikes Loom over Islamic State Extremists in Iraq: Why Now?' $(C N N)$

<http://www.cnn.com/2014/08/08/world/meast/iraq-airstrikes-why-now/in dex.html $>$ accessed 8 August 2014.
} 
against Israel and her population is also a violation of human rights law and can be a cause of action for international judicial governance.

Any change of state of affairs by the United Nations must be handled with due precautions as we shall discuss under the UN tribunal.

The adjudication process of such hard decisions are not going to be easy since no any world Court has jurisdiction over religious conflicts or political crimes of that magnitude. There are no proper multilateral religious treaties to accord religious groups with legal protection besides human rights and humanitarian law provisions.

\section{United Nations Tribunal}

Russell Tribunal (UNISPAL) was created by the United Nations to deal with inalienable rights of the Palestinian people. Racial discrimination and acts of apartheid are all prohibited by the international law. ${ }^{41}$ Erecting of barrier by the Israel authority was alleged as an act of apartheid against the Palestinian people. ${ }^{42}$ Russell Tribunal on Palestine made it loud and clear that the Israeli settlements in the Gaza Strip (Camp David Accord) is illegal by law. ${ }^{43}$ Likewise the same report made it again loud and clear that suppressions and oppressions of the Palestinian population by Israel was in breach of the international law due to alleged occupation of 1967 following Camp David Accord. Israel's Cast Lead Operations in Gaza involved prohibited weapons in violation of the Fourth Geneva Convention of 1949.

But what all these reports have done is to deplore and condemn without serious legal commitments on criminal acts of Israel against the Palestinian people as stated in the following citation.

The will of "we the people of these United Nations" is that all our brothers and sisters should be free to live in selfdetermination, that the oppressed should be released from their burden, by being given recourse to the law, and that the oppressors should be called to account by that same law. ${ }^{44}$

Based on this report no embargo has ever been imposed on Israel by the UNSC watering down any legal sanction on member State. However voting for the changing of Palestine from Observer State status to a Non-Member Observer State status on $29^{\text {th }}$ November 2012 during the $67^{\text {th }}$ Plenary Meeting of the General Assembly, shifts the attention towards, "Two-State Solution" with full recognition of the independence of Palestine (GA/11318; PAL/2155) ${ }^{45}$

\footnotetext{
41 'Roger Waters Speech at the UN | Russell Tribunal on Palestine' $<$ http://www.russelltribunalonpalestine.com/en/sessions/future-sessions/vid eos/roger-waters-speech-at-the-united-nations-on-29-november $>$ accessed 6 August 2014.

Yasmine Hafiz, 'ISIS Destroys Jonah's Tomb In Mosul, Iraq, As Militant Violence Continues' (Huffington Post, 25 July 2014) $<$ http://www.huffingtonpost.com/2014/07/25/isis-jonah-tomb_n_5620520. html $>$ accessed 7 August 2014

42 Ibid.

43 'Settlement in the Middle East: What Would It Look Like and Can We Get There from Here: Discussion' (1983) 77 American Society of International Law Proceedings 285.

44 'Roger Waters Speech at the UN | Russell Tribunal on Palestine' (n 41).

45 'Journal of International Criminal Justice' (n 26).
}

The fate of Palestine has been anchored on her recognition as an independent full member State of the United Nations, therefore, her capacity to enter into diplomatic relations with other States including Israel (Two-State Solution). Meanwhile the independent Palestine State has already expressed her intention to accede to the Rome Statute ${ }^{46}$, a move that may enable her to charge Israel for illegal settlements in her territory. ${ }^{47}$ In January 2015 the state of Palestine acceded to the Rome Statute making it easier for the court to open investigations into the situation of Palestine over the crimes committed in the occupied Palestine territory pursuant to Art. 12(3) of the Rome Statute.

\section{Hostilities and Inhumane Treatment of the Victims}

History has it that the war of liberation in Palestine of 1948 left many dead and several casualties. The war which was known as Arab-Israeli War of 1948 which ended with the Armistice Agreements of 1949 was considered as the war of liberation under the principle of the self-determination of the people. The agreement brought many changes, Transjordan took control over West Bank, Strip of Gaza was under control of Egypt and Syria took the control of Himmah area. Fierce war erupted again in 1967 between Israel and Egypt that lasted 6 days. Israel managed to claim Sinai Peninsula from Egypt, West Bank from Transjordan ${ }^{48}$, and Golan Heights from Syria seizing control over Gaza Strip. After this war experience Palestinian leadership broke ranks with Jordan in 1970 and in 1974 Palestinian Liberation Organization was initiated and at Rabat Summit Conference, PLO was declared the representative authority of the Arab Palestinians but with its headquarter restricted in Ramallah and not Jerusalem. Palestinian Declaration of independence then came up in 1988 with PLO as the recognized authority representing the voice of the Palestinian people. UN General Assembly Resolution 181 (Partition Plan of 1947) supported rights of Palestinians and Palestine.

In 2007 there was historical split between Al Fatah and Hamas groups. The separation involved violations of humanitarian law and many casualties were reported thereafter. The battle field was mainly in the Gaza Strip which broke the government of national unity between the two rival Palestinian movements. Hamas that presented itself as a militant entity and Al Fatah that appeared to be more diplomatic and in favour of negotiations stood at the centre of the cause of violence. Israel kept on its occupation and use of violence to prevent the rivals from attacks on its population. ${ }^{49}$ However, despite all this historical analysis it is imperative to question the legality of such attacks and

\footnotetext{
46 'ICC - Palestine' <http://www.icc-cpi.int/en_menus/icc/structure\%20of $\% 20$ the $\% 20$ court/office $\% 20$ of $\% 20$ the $\% 20$ prosecutor/comm $\% 20$ and $\% 20$ re f/pe-ongoing/palestine/Pages/palestine.aspx $>$ accessed 9 March 2015.

${ }_{47}$ Kontorovich (n 28).

48 'Settlement in the Middle East: What Would It Look Like and Can We Get There from Here: Discussion' (n 43).

49 'State of Palestine' (n 31).
} 
counter attacks from both sides and establish if there is a case for the ICC to intervene.

\section{The Legality of Israeli Offensive in Gaza}

In the middle of July 2014, after Hamas had fired their missiles into the sovereign state of Israel, the offensive and defensive from both High Contracting Parties intensified with Israel using air and land means to destroy Hamas and its networks in the Gaza Strip. ${ }^{50}$ Worsening the situation, a militant group emerging in Iraq that call itself Islamic State in Iraq and Syria (ISIS) is threatening to join Hamas in the fight against "the barbaric Jews". ${ }^{51}$ The unfolding situation of war might get out of proportion should the United Nations Security Council fail to provide quick solution. Iraq falling into the hands of jihadists whose casus bellis seems to reflect more on religious hatred other than the liberation conflicts in the region. They rampage cultural properties including none Muslim civilian objects.

World international media is full of this information as the international community is making invaluable efforts through diplomatic mediations conducted by the United Nations, USA and the UK. Both Israel and Hamas are blaming each other for war crimes, crimes against humanity, crimes of aggression ${ }^{52}$ in time of peace or in time of war. Incurred humanitarian tragedy is huge as none of the High Contracting Parties is ready to cede ground despite several calls to stop humanitarian catastrophe facing many civilians and their objects in the region.

If Hamas is fighting on behalf of the State of Palestine then the armed conflict meets the threshold of the International Humanitarian $\mathrm{Law}^{53}$ as an International Armed Conflict. The scene of war crime is majorly within the Gaza Strip, or the stronghold of the militant Hamas. ${ }^{54}$ It is not yet clear within the international law whether Hamas is recognized as part of the Government of the State of Palestine and if their use of force is considered legitimate or an insurgent within the free State of Palestine.

Considering the pedigree of war, the casus belli is extensively wide however the interest of this research is limited to jus in bello (law applicable during conflicts) rather than jus ad bellum (the law regulating resort to the use of force).$^{55}$ The concern here is the rules of international law and domestic laws applicable during the hostilities and if such use of force is within the law.

Children $^{56}$, women ${ }^{57}$ and all other category of protected

\footnotetext{
50 'Israel \& Palestine: A Tragedy in Three Acts' $<$ http://rt.com/op-edge/177 764-israel-palestine-tragedy-argentina/> accessed 4 August 2014.

${ }_{51}$ 'Israel \& Palestine: A Tragedy in Three Acts' (n 19).

52 'ElementsOfCrimesEng.pdf' (n 17).

${ }^{53}$ Elizabeth Wilmshurst, Susan Carolyn Breau and British Institute of International and Comparative Law, Perspectives on the ICRC Study on Customary International Humanitarian Law (Cambridge University Press 2007).

54 'Israel \& Palestine: A Tragedy in Three Acts' (n 19).

${ }_{55}$ Naorem Sanajaoba, A Manual of International Humanitarian Laws (Regency Publications 2004).

56 'Deadly Israeli Strikes Hit UN School, Market Area' (Yahoo News)
}

persons are not spared in this brutal war $^{58}$ as already stipulated in in the Customary International Humanitarian Law. ${ }^{59}$ Secretary-General Ban Ki-moon ${ }^{60}$ called the school shelling "outrageous" and "unjustifiable," ${ }^{61}$ and demanded an immediate humanitarian cease-fire. ${ }^{62}$

Asked about their opinion in regard to this war, Palestinians still believe that this war is legitimate even if it does not meet the grounds of legality principle due to occupation allegations. ${ }^{63}$

"Today there is a national consensus on the resistance as Israel continuously attacks. I refer to a group of Palestinian military factions who brought hope and spirit to occupied Palestinians, and Arabs alike. The Palestinian resistance has the ability to crack down on the Israeli occupation known 'as the army never defeated,' one of the most strategic and powerful military forces in the world. - See more at: http://www.middleeasteye.net/news/what-do-gazans-think-h amas-abbas-and-israels-strikes-670465287\#sthash.Cff5Sw MZ.dpuf

In the eyes of high profile personalities this is a barbaric war ${ }^{64}$ that must be considered as one of the war crimes and crimes against humanity in disregard to the causality of the hostilities ${ }^{65}$. It beats all logic to argue that the ICC does not have jurisdiction over the Gaza Strip or Israel or over perpetrators. At the same time it is not in order for the United Nations Security Council to peg its decision to intervene and restore peace and security on the veto powers ${ }^{66}$ that are always divided and influenced by their vested interests in the Middle East. ${ }^{67}$

Bombing schools ${ }^{68}$, hospitals and places of worship are all prohibited by the international law of war and the law of Geneva. A wide-spread or systematic attack against civilian populations and their objects in such a ruthless manner has been adversely condemned not only by World civilized nations but also the UN Office of the High Commissioner for Human Rights that has alleged to call for prosecution of

$<$ http://news.yahoo.com/deadly-israeli-strikes-hit-un-school-market-area-2 15854095.html > accessed 4 August 2014.

${ }^{57}$ E van Sliedregt, The Criminal Responsibility of Individuals for Violations of International Humanitarian Law (Asser Press 2003).

58 'ElementsOfCrimesEng.pdf' (n 17).

59 International Committee of the Red Cross and others, Customary International Humanitarian Law (Cambridge University Press 2005).

${ }^{60}$ United Nations News Service Section, "UN News - Briefing UN Assembly, Ban Urges Political Talks to End "senseless Cycle of Suffering" in Gaza' (UN News Service Section, 6 August 2014) $<$ http://www.un.org/apps/news/story.asp?NewsID $=48426 \& C r=$ palestin $\& C r$ $1=\# . U-L q v 2 P z v 8 c>$ accessed 7 August 2014.

${ }^{61}$ United Nations News Service Section, 'UN News - Gaza: Ban Condemns Latest Deadly Attack near UN School as "Moral Outrage and Criminal Act", (UN News Service Section, 3 August 2014) < http://www.un.org/apps/news/ story.asp?NewsID=48396\#.U-LrYmPzv8c $>$ accessed 7 August 2014.

62 'Deadly Israeli Strikes Hit UN School, Market Area' (n 56).

63 'What Do Gazans Think of Hamas, Abbas and Israel's Strikes?' (Middle East Eye) <http://www.middleeasteye.net/news/what-do-gazans-think-ham as-abbas-and-israels-strikes-670465287> accessed 4 August 2014.

64 'Palestinians Accuse Israel of War Crimes, Push for ICC Trial Gets Support Online' (n 1).

65 'ElementsOfCrimesEng.pdf' (n 17).

66 'Gaza: Law of War Needs Testing at International Criminal Court' (The Sydney Morning Herald) <http://www.smh.com.au/comment/gaza-law-ofwar-needs-testing-at-international-criminal-court-20140801-zzaxa.html> accessed 4 August 2014.

67 'Roger Waters Speech at the UN | Russell Tribunal on Palestine' (n 41).

68 'Deadly Israeli Strikes Hit UN School, Market Area' (n 56). 
Israel. ${ }^{69}$ The former UN High Commissioner Navy Pillay criticized both Israel and Hamas for the violations of human rights law by saying: ${ }^{70}$

Israel's airstrikes and military actions in the Gaza Strip could amount to war crimes, the UN's high commissioner for human rights said in Geneva on Wednesday. Navi Pillay cited cases of Israeli airstrikes or shelling hitting houses and hospitals in Gaza. ${ }^{71}$

UN Secretary-General Ban ki-Moon call for diplomatic negotiations while Israel and Hamas trade on blames. ${ }^{72}$ The destruction of humanity remains unacceptable. In this case negotiations and mediations seem to have failed and the international community can only apply international criminal justice as the alternative.

A French lawyer has moved to the ICC on behalf of the Government of Palestine to bring justice to the Palestinian population. ${ }^{73}$ The charges are on the counts of war crimes against Israel and the response of the ICC shall be vital. How about the attacks by Hamas on Israel? Is there any military necessity and do the two apply the rule of proportionality in actions of offensive and defensive?

\section{Military Necessity and the Application of the Principle of Proportionality}

Israeli Government quotes acting in legitimate self-defence in safeguarding the rights of its population which is an obligation of every State under the international law. Alberto R. Coll explains that ${ }^{74}$ Hamas started it with their rocket attacks, Israel is only defending itself. ${ }^{75}$ The same perception moved the same government to erect barrier in the West Bank a move that was heavily disputed and challenged in the national and international circles as an act of apartheid. ${ }^{76}$ The questions that follow are: is there military necessity; and are the deployed measures compatible with the international law principle of proportionality?

To understand the above questions it is necessary, therefore, to start by questioning the role of the jus in bello or the applicable international law that would limit the suffering

\footnotetext{
69 Mohamed Chande Othman, Accountability for International Humanitarian Law Violations The Case of Rwanda and East Timor (1 edition, Springer 2005)

"UN's Pillay: "Strong Possibility" of Israeli War Crimes | News | DW.DE 23.07.2014' (DW.DE)<http://www.dw.de/uns-pillay-strong-possibility-ofisraeli-war-crimes/a-17801640> accessed 4 August 2014

${ }_{11}$ Ibid.

72 Ibid.

3 'Middle East - French Lawyer Files Complaint against Israel at ICC' (France 24)

<http:/www.france24.com/en/20140725-israel-icc-war-crimes-gaza-compl aint-filed/> accessed 4 August 2014.

74 'Settlement in the Middle East: What Would It Look Like and Can We Get There from Here: Discussion' (n 43).

${ }_{75}$ 'Roger Waters Speech at the UN | Russell Tribunal on Palestine' (n 41).

76 'Israeli Supreme Court Opinions on the West Bank Barrier', , Wikipedia, the free encyclopedia (2014)

$<$ http://en.wikipedia.org/w/index.php?title=Israeli_Supreme_Court_opinio $\mathrm{ns}$ on the West Bank Barrier\&oldid $=60607163 \overline{0}>$ accessed $6^{-}$August 2014 .
}

caused by war and if the legality of such use of force is considered. Which are the coercive measures to restore peace against State threatening international peace and security? Are there effective peace-keeping measures adopted by the UN Security Council to ensure that there is lasting peace in the most troubled region?

In 1965, the UN General Assembly adopted resolution $2105(\mathrm{XX})$ the right of peoples to self-determination legitimizing the struggle waged by peoples under colonial domination to exercise their right to independence. This resolution has favoured Palestinian Liberation Organization as the legitimate body to represent Palestinian people in the struggle for independence. The Hamas in Gaza Strip has been accusing Israel authority of occupation and oppression of the people of Gaza, a claim that may fit well with war of liberation. However, both belligerents must observe customary law of war and respect minimum standards.

The situation of Gaza Strip appears to be more of act of insurgents or internal disturbances other than international armed conflict. Hamas launching missiles and suicide bombers (kamikaze) aiming to kill Israeli population do not match the real sense of war involving combatants against combatants but combatants against civilians and vice-versa. In several occasions Israel authority has referred to Hamas as terrorist group other than official army an allegation suggesting that Israel is fighting the war on terrorism.

Reprisal attacks and counter accusations provide another ground for possible legal interest on both parties. Gaza authority claims that Israel must unconditionally liberate its nationals that are detained in Israeli jails. Another claim is that Israel should stop the settlements in the territory of Gaza and surrender occupied sites to Palestine.

\section{The Legal Personality of Hamas}

Before establishing any credible judicial process, it is necessary to examine in details the legal identity of Hamas group in the hostilities. Is it an incorporated body that can stand charges at the ICC ${ }^{77}$ Does the ICC have jurisdiction over insurgent groups, terrorist entities ${ }^{78}$, Governments, or any corporate? International Criminal Court has prosecutorial jurisdiction over individual physical persons suspected of international crimes under the principle nullum crimine sine lege ${ }^{79}$ in the rules of procedure and evidence. In case of any investigation, what matters most shall be individuals who bear the highest responsibility and the existence of the law to warrant any cause of action. ${ }^{80}$

The tragedy in Gaza Strip has political implications (border issues) which do not fall under the jurisdiction of the ICC and for this particular reason, it is within the capacity of

\footnotetext{
77 'ROME STATUTE.pdf' (n 7).

78 'LIVE UPDATES: Violent Clashes Resume across Israel; IDF Strikes Gaza - Diplomacy and Defense' (Haaretz.com) <http://www.haaretz.com/n ews/diplomacy-defense/.premium-1.603274> accessed 4 August 2014.

${ }^{79}$ 'RulesProcedureEvidenceEng.pdf'

$<$ http://www.icc-cpi.int/iccdocs/PIDS/legal-texts/RulesProcedureEvidence Eng.pdf $>$ accessed 9 March 2015.

'UICCEng.pdf' (n 21)
} 
the United Nations and its institutions to deal pragmatically with the alleged crimes in the Middle East. The Union of the Comoros a member of the State Parties to the ICC referred the case of the Gaza Flotilla Report to the ICC for investigation on material incidents that involved its vessel meant to deliver humanitarian aid to the people of Gaza $^{81}$ against Israel Defence Forces (IDF). Comoros felt offended since the vessel was flying the flag of Comoros in the international waters and damages were caused.

Hamas is not the government and cannot refer its cases to the ICC unless it is the Government of the State of Palestine subject to the fact that it must recognise the jurisdiction of the Court.

\section{Admissibility Provision of the Rome Statute}

Any member State of the Rome Statute can refer a situation to the ICC office of the Prosecutor for criminal investigations. ${ }^{82}$ The State can invite the Chief Prosecutor ${ }^{83}$ to investigate in the alleged criminal situation as has been the case in the DRC, Ivory Cost and few others. United Nations Security Council can as well make a request to the ICC to intervene in a situation of crime as has been the case of Sudan and Libya. The other option is that the Chief Prosecutor can use the discretion of the office and the principle of proprio motu ${ }^{84}$ to open an investigation in any State where criminal offense ${ }^{85}$ has taken place with the condition that the State concerned is unable or unwilling to prosecute as in Kenyan situation. ${ }^{86}$

International law seems eyeless in Gaza. For more than two weeks the world has watched war crimes apparently committed by both sides: lethal attacks on schools and hospitals, rocket showers aimed at civilians, tunnels chillingly lined with syringes and ropes, and always, the dead and dying children. Now the call goes up from politicians and prelates and the UN Secretary-General for "accountability" and "responsibility" and "justice". That should mean a proper forensic investigation with criminal charges against commanders if the evidence warrants, heard in an international criminal court. It is important to understand why this could happen and why it probably will not. $^{87}$

Read more: http://www.smh.com.au/comment/gaza-lawof-war-needs-testing-at-international-criminal-court-201408 01-zzaxa.html\#ixzz39QgmVyxl

There is, after all, an International Criminal Court in The Hague, with a prosecutor equipped to investigate and to charge (under article 8 of the ICC statute) precisely those crimes that seem to be occurring in the present conflict. But

\footnotetext{
81 'doc1615044.pdf' <http://www.icc-cpi.int/iccdocs/doc/doc1615044.pdf> accessed 9 March 2015.

82 'ROME STATUTE.pdf' (n 7).

83 'UICCEng.pdf' (n 21).

84 'ROME STATUTE.pdf' (n 7).

${ }^{85}$ Dugard (n 25).

86 'RulesProcedureEvidenceEng.pdf'.

87 'Gaza: Law of War Needs Testing at International Criminal Court' (n 66)
}

her power to act arises only in two relevant circumstances. First, by a reference from the Security Council, which is sure to be blocked by one - if not all - of the five permanent members. By the US (always protective of Israel), by Russia (afraid of where a criminal investigation of MH17 might lead), and by China (obsessed with state sovereignty)... ${ }^{88}$

Read more:

http://www.smh.com.au/comment/gaza-law-of-war-needs-t esting-at-international-criminal-court-20140801-zzaxa.html \#ixzz39QhYDlpI

\section{Challenges Facing the ICC}

A part from the unwillingness of the veto powers in the United Nations Security Council to impose sanctions on Israel it is also evident that Israel is not a signatory State to the Rome Statute, neither was Palestine during the time of hostilities. ${ }^{89}$ (The status of the state of Palestine has since changed in 2015 $)^{90}$. Another challenge is between Hamas that commands the Gaza Strip and the PLO and the Government of the State of Palestine under Al Fatah. Hamas is not the Government of the State of Palestine and does not represent the rights of the Palestinians. Hamas has no locus standi to take its cases to the ICC but the Government of Palestine acceded to the Rome Statute ${ }^{91}$ to refer its cases to the ICC after recognizing its jurisdiction (Palestine has since applied to be a state party to the Rome statute). The same applies to the Government of Israel that can accede to the Rome Statute then refer its cases to the ICC for international prosecution after recognizing its jurisdiction.

But a controversial question is, can one State take another State to the Criminal Court whose jurisdiction is not to prosecute a sovereign State or a government? The State can only take individual perpetrators to the ICC but such individual must be her national. If Palestine accedes ${ }^{92}$ to the Rome Statute then she can take her nationals to the ICC as Ivory Coast did in the case facing its former Head of State. But Palestine taking Israel nationals to the ICC for prosecution is not contemplated in the Rome Statute, therefore, unlawful.

However, a State party to the Rome Statute can only refer her own national/s to the ICC, for instance, Ivory Coast through its Government had to refer the case of Laurent Gbagbo to the ICC for criminal prosecution. Israel cannot refer members of Hamas to the ICC nor can Palestine refer any citizen of Israel to the ICC since this may sound political move. $^{93}$

Israel has proper legal institutions that can prosecute criminal offences within her jurisdiction and there is no sign of any state failure or unwillingness to do so that would

\footnotetext{
88 Ibid.

89 'Roger Waters Speech at the UN | Russell Tribunal on Palestine' (n 41).

90 'ICC - Palestine' (n 46).

91 'Palestine'

$<$ http://www.icc-cpi.int/en menus/asp/states\%20parties/asian\%20states/Pa ges/Palestine.aspx $>$ accessed 9 March 2015.

92 Ibid.

93 'UICCEng.pdf' (n 21).
} 
trigger off the proprio motu of the Office of the Prosecutor to act. The Chief Prosecutor of the ICC cannot intervene in a situation that does not prove incapacity of the State or unwillingness to prosecute the offences within its jurisdiction. ${ }^{94}$ Gaza Strip is under the State of Palestine and Israel has no locus standi to prosecute crimes taking place in another sovereign State. This may breach the territorial integrity of the State of Palestine and cause serious interference into internal affairs of another sovereign state.

Purportedly, the attacks by launching missiles and bombarding another sovereign state are covered within the international law of war or Military law in the customary international law. Severally states have reported disputes and grievances concerning borders to the International Court of Justice (ICJ) composed of 15 judges bench for adjudication or to the United Nations Security Council for deliberations.

The ICC has no jurisdiction on state conduct nor does it have power to stop international or non-international warfare. The ICC contains an analogous jurisdiction ${ }^{95}$ but not identical with its counterpart the ICJ in the nature of offences committed within the international law. The general feeling is that no state is willing to allow its military officers to be prosecuted outside her jurisdiction and the state practice has been that military offences are customarily dealt with by national martial courts.

The successful story of Nuremberg Tribunal established by the United Nations of 1950s was exceptional and was all done in the Federal State of Germany where the crimes occurred under the auspices of the United Nations. It is within the international customs that States prefer prosecuting their own military offences and the ICC does not have any jurisdiction over such matters unless the state is unwilling to prosecute. ${ }^{96}$

General perception of the international criminal law is that war crimes must be dealt with as close as possible to the national judicial authorities as in the Special hybrid Court of Cambodia. ${ }^{97}$ The practice in the international law sentiment is that national courts must enshrine within their statutory law provisions on international crimes such as war crimes as per the complementarity principle of the Rome Statute. The reason is that war crimes are delicate and the ICC should not act on them exclusively of the collaboration of the affected sovereign states.

Ensuring justice is, first and foremost, the responsibility of national courts. For the purposes of a lasting peace, it is crucial that justice take place as close as possible to the place where the crime was committed. States are therefore obligated to exercise their criminal jurisdiction over those responsible for international crimes. The purpose of this seminar is to discuss particular challenges confronting States in their efforts to import core international crimes into their national criminal law. ${ }^{98}$

Does the ICC have universal jurisdiction over criminal

\footnotetext{
${ }^{94}$ Ibid.

95 'ICC Opens Investigation of Gaza War' (n 16).

${ }^{96}$ Ibid.

97 'INT CRIMINAL LAW.pdf'.

${ }^{98}$ Ibid.
}

cases? The answer is no. ${ }^{99}$ It is a treaty Court meant to bind exclusively on its state parties unless the request comes from the United Nations Security Council for it to intervene or a state accedes to the statute and refers its own national/s to the Court. But it has international jurisdiction in that it can prosecute any offence within its jurisdiction but not universal jurisdiction.

The UN Partition plan of the two - State option appears not to be accepted by some UN member States for reasons beyond the scope of this paper. The erection of protection barrier ${ }^{100}$ around the Israel territory on the principle of legitimate self- defence and the continuation of the military occupation are all regimes that keep on creating more questions than answers from both sides of political divide. ${ }^{101}$

Then there is the alternative basis for empowering the ICC prosecutor: a state party to the ICC treaty (and there are presently 122) may require the prosecutor to investigate international crimes committed on its territory or by its people. Israel has refused to ratify the treaty, thereby depriving itself of a means to hold Hamas to account for rocket attacks and leaving the territory of Gaza (which it dubiously claims not to "occupy") an open question. Can the State of Palestine, were it to ratify the treaty, invoke an ICC investigation into war crimes in Gaza? In 2009 it attempted to do just that in seeking a remedy for "Operation Cast Lead", but the prosecutor refused to accept that it was enough of a state to be entitled to become a party to the treaty. However, in November 2012 the General Assembly accorded Palestine the status of statehood - as a non-member observer state, but a state nonetheless. It has since been permitted to become a state party to 13 international treaties. Might it now - today - accede to the ICC treaty and with the appropriate declarations under that treaty invite the prosecutor to investigate war crimes committed in the territory of Gaza since November 29, $2012 ?^{102}$

Read more: http://www.smh.com.au/comment/gaza-lawof-war-needs-testing-at-international-criminal-court-201408 01-zzaxa.html\#ixzz39QkUrT18

\section{Violations of Humanitarian and Human Rights Law}

Despite all the attempts to stop the armed conflict in the Gaza Strip and the Middle East for humanitarian purpose, the situation remains volatile as many casualties are reported. ${ }^{103}$ Death toll keeps on rising whereas hospitals are running out of drugs and facilities. The atrocities of the armed conflict in Gaza match the elements of crimes under the International

\footnotetext{
99 'UICCEng.pdf' (n 21).

100 'Israeli Supreme Court Opinions on the West Bank Barrier' (n 76).

101 'Israel \& Palestine: A Tragedy in Three Acts' (n 19).

102 'Gaza: Law of War Needs Testing at International Criminal Court' (n 66).

${ }_{103}$ 'Gaza Death Toll Higher than Thought: Palestinian Envoy' (Middle East Eye)

$<$ http://www.middleeasteye.net/news/gaza-death-toll-higher-thought-palest inian-envoy-2061424487> accessed 4 August 2014.
} 
Criminal Court guiding principles ${ }^{104}$.

Members of the ICRC are putting possible efforts to assist the victims of war as provided for by the IHL. If the situation is not stopped in time then human disaster shall be great and many more militant groups such as ISIS ${ }^{105}$ and perhaps some sympathising States such as Iran may join Hamas to tame Israel. At the same time, Israel will not be isolated and her alliances may as well pile pressure in support of the Jews people living in the region, a situation that may bring crisis in the international intercourse of States after the Second World War.

The dilemma expressed by the ICC may become a recipe to another world war since the international community does not share the same political ideology. Another probable consequence may be the unfolding jihadist war that likewise must be tamed by all means. ${ }^{106}$ The new insurgence alludes that the war is about Islam and Judeo-Christian Religions seeking to define another aspect of the Gaza crisis. ${ }^{107}$ Should this latter be the case then the world opinion ${ }^{108}$ may hypothetically realigned towards inter-religious polarization and yield into war of religion as been witnessed in Nigeria and Central African Republic where Muslims and Christians have been killing each other ${ }^{109}$.

The International Criminal Court was not designed to deal with war of ideologies especially the war of religion. Palestine - Israeli war should not take the direction of religious warfare ${ }^{110}$ which may be difficult to stop. At the same time, religious leaders fear talking about the jihadist conflict. ${ }^{111}$ Failure to act or laissez faire attitude is a crime of omission that may not add value to the world effort to maintain world peace and security through criminal justice process.

Another challenge facing the ICC and its jurisdiction in the world criminal justice is the terrorism and counter terrorism criminal offences. ${ }^{112}$ "Terrorism" ${ }^{113}$ has not been well defined and its interpretation in the international law is not yet made clear. Meanwhile states are aware of the tragedies caused by the crime of terrorism ${ }^{114}$ but have not agreed on its interpretation and how to bring it to international justice system. Apparently, it is clear that every

\footnotetext{
104 'ElementsOfCrimesEng.pdf' (n 17).

105 "Islamic State to Join Palestine to Fight the "Barbaric Jews", (Breitbart News Network) < http://www.breitbart.com/Big-Peace/2014/08/01/IslamicState-to-Join-Palestine-to-Fight-the-Barbaric-Jews $>$ accessed 4 August 2014.

106 'Iraq Jihadists Seize Another Town from Kurdish Forces' (Yahoo News) $<$ http://news.yahoo.com/jihadists-seize-iraqi-town-sinjar-kurds-110159527 .html> accessed 4 August 2014.

107 'Islamic State to Join Palestine to Fight the "Barbaric Jews"' (Breitbart News Network)

$<$ http://www.breitbart.com/Big-Peace/2014/08/01/Islamic-State-to-Join-Pa estine-to-Fight-the-Barbaric-Jews $>$ accessed 4 August 2014.

108 'Palestinians Accuse Israel of War Crimes, Push for ICC Trial Gets Support Online' (n 1).

109 'ElementsOfCrimesEng.pdf' (n 17).

110 "Islamic State to Join Palestine to Fight the "Barbaric Jews"' (Breitbart News Network)

$<$ http://www.breitbart.com/Big-Peace/2014/08/01/Islamic-State-to-Join-Pal estine-to-Fight-the-Barbaric-Jews $>$ accessed 4 August 2014.

111 'Iraq Jihadists Seize Another Town from Kurdish Forces' (n 105).

112 'TERRORISM.pdf'

113 Gregory E Maggs, Terrorism and the Law Cases and Materials (American Casebook) (West Group Publishing 2005).

114 'HUMAN RIGHTS TERRORISM.pdf'.
}

single State tends to enact laws that would deal with crimes of terrorism taking place within its jurisdiction.

Hamas fighters usually hide themselves among the civilian populations causing Israeli fighters to attack their hide-outs including residential areas and institutions. This is a serious legal challenge in the case of Gaza Strip affecting civilian populations caught up in cross-fire.

\section{Remarks}

The role of the ICC in the current on-going armed conflicts is evidently very low and progressively under control. The question of admissibility of situations to the court is still problematic. The ICC, though respects the admissibility provision of the Rome Statute, still requires more research and how to best deal with unfolding international criminal offences seeking more legitimacy from the Assembly of State Parties. ${ }^{15}$

It is also remarkable that the ICC is a treaty Court unlike the ICJ which is a Charter Court therefore can deal with inter-border disputes between states. The two world courts have distinct jurisdictions and competence in the international law. The ICC has limited jurisdictions dealing only with criminal offences as stipulated in the Rome Statute and not civil offences.

No State is compelled or is under obligation to accede to the Rome treaty known as the Rome Statute. The treaty (the statute) can be terminated with a resolution of the majority of signatories voting against it and that would be the end of the court. Instead, all members of the UN are also automatically subscribers of the Statute of the ICJ according to the Charter. And the Charter requires a more difficult process to be terminated or amended by State members. Both courts are permanent but the ICC is more limited as compared to the ICJ.

The ICC may not deliver on its mandate if not fully supported by the majority of the Assembly of State Parties and the United Nations. Its financial support relies on the Assembly of State Parties whereas the ICJ gets support from all members of the United Nations.

Purporting that legal norms are powerless in themselves to transform the states' criminal conduct, it is possible that the ICC could find it cumbersome to intervene in politically inspired use of violence. ${ }^{116}$ There are many questions than answers in the chronic fight in the Middle East due to the nature and causality of such hostilities. As much as one may think that the Arab - Israeli war is over, there is the sentiment of jihad, ${ }^{117}$ holocaust and historical wrongs that still the international community must address before considering international criminal justice.

\footnotetext{
115 'COUNTER TERRORISM MEASURES VERSUS HUMAN RIGHTS.pdf'.

116 'Settlement in the Middle East: What Would It Look Like and Can We Get There from Here: Discussion' (n 43).

117 "Islamic State to Join Palestine to Fight the "Barbaric Jews", (Breitbart News Network)

$<$ http://www.breitbart.com/Big-Peace/2014/08/01/Islamic-State-to-Join-Pal estine-to-Fight-the-Barbaric-Jews $>$ accessed 4 August 2014.
} 
This research paper is just a tip of the iceberg of the problem engulfing the entire region while the United Nations is treading with precautions and prudence in matters concerning international criminal law due to its sensibility. ${ }^{118}$

In conclusion, the dispute between Israel and Palestine will be more favourably solved through political and diplomatic other than judicial and military necessities. The ICC does not deal with ideologies and political facts surrounding the hostilities in the Gaza Strip. Rome Statute of 2002 does not have retroactive jurisdiction and cannot deal with historical offences before its adoption. Yet we cannot, at the same time, dismiss the need for international order and the rule of law entailed in the international peace and security. Rome Statute was drafted to tame impunity of states in international crimes and the ICC will only be fair to consider all legal means at its disposal to mitigate destruction of the humanity that took place in 2002 and after.

\section{REFERENCES}

[1] 'Airstrikes Loom over Islamic State Extremists in Iraq: Why Now?' (CNN)

$<$ http://www.cnn.com/2014/08/08/world/meast/iraq-airstrike s-why-now/index.html $>$ accessed 8 August 2014

[2] Beigbeder Y, International Justice Against Impunity Progress And New Challenges (Brill Academic Pub 2005)

[3] _- International Justice Against Impunity Progress And New Challenges (Brill Academic Pub 2005)

[4] Burke J, 'Rafah Residents Count Human Cost of Israeli Offensive' The Guardian (3 August 2014) $<$ http://www.theguardian.com/world/2014/aug/03/rafah-resi dents-count-human-cost-israeli-offensive $>$ accessed 4 August 2014

[5] Carenen C, 'The American Christian Palestine Committee, the Holocaust, and Mainstream Protestant Zionism, 19381948' (2010) 24 Holocaust and Genocide Studies 273

[6] 'COUNTER TERRORISM MEASURES VERSUS HUMAN RIGHTS.pdf’

[7] Cross IC of the $\mathrm{R}$ and others, Customary International Humanitarian Law (Cambridge University Press 2005)

[8] 'Deadly Israeli Strikes Hit UN School, Market Area' (Yahoo News)

$<$ http://news.yahoo.com/deadly-israeli-strikes-hit-un-schoolmarket-area-215854095.html> accessed 4 August 2014

[9] 'doc1615044.pdf'

$<$ http://www.icc-cpi.int/iccdocs/doc/doc1615044.pdf $>$ accessed 9 March 2015

[10] Dugard J, 'Palestine and the International Criminal Court Institutional Failure or Bias?' (2013) 11 Journal of International Criminal Justice 563

\footnotetext{
118 'Iraq Jihadists Seize Another Town from Kurdish Forces' (Yahoo News) $<$ http://news.yahoo.com/jihadists-seize-iraqi-town-sinjar-kurds-110159527 .html $>$ accessed 4 August 2014
}

[11] 'ElementsOfCrimesEng.pdf' $<$ http://www.icc-cpi.int/NR/rdonlyres/336923D8-A6AD-40 EC-AD7B-45BF9DE73D56/0/ElementsOfCrimesEng.pdf> accessed 9 March 2015

[12] 'Gaza Death Toll Higher than Thought: Palestinian Envoy' (Middle East Eye)<http://www.middleeasteye.net/news/gaza -death-toll-higher-thought-palestinian-envoy-2061424487> accessed 4 August 2014

[13] 'Gaza: Law of War Needs Testing at International Criminal Court' (The Sydney Morning Herald) <http://www.smh.com. au/comment/gaza-law-of-war-needs-testing-at-internationalcriminal-court-20140801-zzaxa.html $>$ accessed 4 August 2014

[14] Hafiz Y, 'ISIS Destroys Jonah's Tomb In Mosul, Iraq, As Militant Violence Continues' (Huffington Post, 25 July 2014) $<$ http://www.huffingtonpost.com/2014/07/25/isis-jonah-tom b_n_5620520.html $>$ accessed 7 August 2014

\section{[15] 'HUMAN RIGHTS TERRORISM.pdf'}

[16] 'ICC Opens Investigation of Gaza War' $<$ http://honestreporting.com/idns-01182015-icc-investigation $\gg$ accessed 9 March 2015

[17] 'ICC - Palestine' <http://www.icc-cpi.int/en_menus/icc/struc ture $\% 20$ of $\% 20$ the $\% 20$ court $/$ office $\% 20$ of $\% 20$ the $\% 20$ prosecu tor/comm\%20and\%20ref/pe-ongoing/palestine/Pages/palesti ne.aspx $>$ accessed 9 March 2015

[18] 'INT CRIMINAL LAW.pdf'

[19] 'Iraq Jihadists Seize Another Town from Kurdish Forces' (Yahoo News) <http://news.yahoo.com/jihadists-seize-iraqi-t own-sinjar-kurds-110159527.html $>$ accessed 4 August 2014

[20] $($ Yahoo News $)$ $<$ http://news.yahoo.com/jihadists-seize-iraqi-town-sinjar-kur ds-110159527.html $>$ accessed 4 August 2014

[21] "Islamic State to Join Palestine to Fight the "Barbaric Jews", (Breitbart News Network) $<$ http://www.breitbart.com/Big-Pe ace/2014/08/01/Islamic-State-to-Join-Palestine-to-Fight-theBarbaric-Jews> accessed 4 August 2014

[22] (Breitbart News Network) <http://www.breitbart.com/ Big-Peace/2014/08/01/Islamic-State-to-Join-Palestine-to-Fig ht-the-Barbaric-Jews> accessed 4 August 2014

[23] (Breitbart News Network) <http://www.breitbart.com/ Big-Peace/2014/08/01/Islamic-State-to-Join-Palestine-to-Fig ht-the-Barbaric-Jews $>$ accessed 4 August 2014

[24] - (Breitbart News Network) <http://www.breitbart.com/ Big-Peace/2014/08/01/Islamic-State-to-Join-Palestine-to-Fig ht-the-Barbaric-Jews $>$ accessed 4 August 2014

[25] 'Israeli Supreme Court Opinions on the West Bank Barrier', , Wikipedia, the free encyclopedia (2014) $<$ http://en.wikipedia.org/w/index.php?title=Israeli_Supreme Court opinions on the West Bank Barrier\&oldid $=60607$ $\overline{1} 630>$ accessed $\overline{6}$ August 2014

[26] 'Israel \& Palestine: A Tragedy in Three Acts' $<\mathrm{http}$ //rt.com/op-edge/177764-israel-palestine-tragedy-arge ntina/> accessed 4 August 2014

[27] $<\mathrm{http}: / /$ rt.com/op-edge/177764-israel-palestine-tragedy-arge ntina/> accessed 4 August 2014 
[28] 'Journal of International Criminal Justice' $<$ http://jicj.oxfordj ournals.org> accessed 7 August 2014

[29] Kontorovich E, 'Israel/Palestine - The ICC's Uncharted Territory' (2013) 11 Journal of International Criminal Justice 979

[30] 'LIVE UPDATES: Violent Clashes Resume across Israel; IDF Strikes Gaza - Diplomacy and Defense' (Haaretz.com) $<$ http://www.haaretz.com/news/diplomacy-defense/.premiu m-1.603274> accessed 4 August 2014

[31] Maggs GE, Terrorism and the Law Cases and Materials (American Casebook) (West Group Publishing 2005)

[32] 'Middle East - French Lawyer Files Complaint against Israel at ICC' (France 24) <http://www.france24.com/en/2014072 5-israel-icc-war-crimes-gaza-complaint-filed/> accessed 4 August 2014

[33] 'MILITARY LAW'

[34] Othman MC, Accountability for International Humanitarian Law Violations The Case of Rwanda and East Timor (1 edition, Springer 2005)

[35] 'Palestine'

$<$ http://www.icc-cpi.int/en_menus/asp/states\%20parties/asia n\%20states/Pages/Palestine.aspx $>$ accessed 9 March 2015

[36] 'Palestinians Accuse Israel of War Crimes, Push for ICC Trial Gets Support Online'<http://globalvoicesonline.org/2014/07 /26/palestinians-accuse-israel-of-war-crime-push-for-icc-tria l-gets-support-online/> accessed 4 August 2014

[37] 'Roger Waters Speech at the UN | Russell Tribunal on Palestine'

$<$ http://www.russelltribunalonpalestine.com/en/sessions/futu re-sessions/videos/roger-waters-speech-at-the-united-nations -on-29-november> accessed 6 August 2014

[38] 'ROME STATUTE.pdf'

[39] Ruiter D de, Humanitarian Law Selected Documents (International Courts Association 2011)

[40] 'RulesProcedureEvidenceEng.pdf' $<$ http://www.icc-cpi.int/iccdocs/PIDS/legal-texts/RulesProce dureEvidenceEng.pdf $>$ accessed 9 March 2015

[41] Sanajaoba N, A Manual of International Humanitarian Laws (Regency Publications 2004)
[42] Section UNNS, 'UN News - Gaza: Ban Condemns Latest Deadly Attack near UN School as "Moral Outrage and Criminal Act"' (UN News Service Section, 3 August 2014) $<$ http://www.un.org/apps/news/story.asp?NewsID=48396\#. U-LrYmPzv8c > accessed 7 August 2014

[43] —, 'UN News - Briefing UN Assembly, Ban Urges Political Talks to End "senseless Cycle of Suffering" in Gaza' (UN News Service Section, 6 August 2014) $<\mathrm{http}$ //www.un.org/apps/news/story.asp?NewsID=48426\& $\mathrm{Cr}=$ palestin\&Cr1=\#.U-Lqv2Pzv8c $>$ accessed 7 August 2014

[44] 'Settlement in the Middle East: What Would It Look Like and Can We Get There from Here: Discussion' (1983) 77 American Society of International Law Proceedings 285

[45] Sliedregt E van, The Criminal Responsibility of Individuals for Violations of International Humanitarian Law (Asser Press 2003)

[46] 'State of Palestine', , Wikipedia, the free encyclopedia (2014) $<$ http://en.wikipedia.org/w/index.php?title=State_of_Palestin e\&oldid $=619424093>$ accessed 4 August 2014

[47] 'TERRORISM.pdf'

[48] 'UICCEng.pdf' $<$ http://www.icc-cpi.int/iccdocs/PIDS/publications/UICCEn g.pdf $>$ accessed 6 August 2014

[49] 'UN's Pillay: "Strong Possibility" of Israeli War Crimes | News | DW.DE | 23.07.2014' (DW.DE) <http://www.dw.de/ uns-pillay-strong-possibility-of-israeli-war-crimes/a-178016 40> accessed 4 August 2014

[50] 'Use of Force and War' (1984) 11 Australian Year Book of International Law 577

[51] 'What Do Gazans Think of Hamas, Abbas and Israel's Strikes?' (Middle East Eye) <http://www.middleeasteye.net/ news/what-do-gazans-think-hamas-abbas-and-israels-strikes670465287> accessed 4 August 2014

[52] Wilmshurst E, Breau SC and Law BI of I and C, Perspectives on the ICRC Study on Customary International Humanitarian Law (Cambridge University Press 2007)

[53] W G, Malbone, Humanitarian Intervention in International Law as Related to the Practice of the United States (1920) 